\title{
Discrete-Time Hazard Model with Interest Rate for Default Forecast: A Study of Post-2008- Crises In Indonesian Listed Insurance Companies
}

\author{
Ni N. SAWITRI \\ Universitas Trilogi, Jakarta 12760, Indonesia \\ Email correspondence: ninyoman.sawitri@gmail.com
}

\begin{abstract}
This paper is intended to examine the performance of the discrete-time hazard model with interest rate in predicting bankruptcy of listed insurance companies in Indonesia Stock Exchange. The study focuses on the period after the 2008-crises. The study employed 2008-2015 financial data from all insurance companies listed in Indonesia stock market. The author conducted stepwise logistic regression to find particular financial ratios to be included in the model and used interest rate as the baseline hazard rate. To examine the precision of the model, the author placed 2016 as the forecast period.
\end{abstract}

Key words: Default Prediction, Discrete-Time Hazard Model, Insurance companies.

\section{Diskrit-Time Model Hazard dengan Suku Bunga Perkiraan Kegagalan: Sebuah Studi Pos- 2008-Krisis Pada Perusahaan Asuransi Tercatat Indonesia}

\begin{abstract}
Abstrak
Tulisan ini dimaksudkan untuk menguji kinerja model hazard diskrit-waktu dengan tingkat bunga dalam memprediksi kebangkrutan perusahaan asuransi yang terdaftar di Bursa Efek Indonesia. Studi ini berfokus pada periode setelah 2008-krisis. Penelitian ini menggunakan 2008-2015 data keuangan dari semua perusahaan asuransi terdaftar di pasar saham Indonesia. Penulis melakukan regresi logistik bertahap untuk menemukan rasio keuangan tertentu untuk dimasukkan dalam model dan digunakan tingkat suku bunga sebagai tingkat bahaya dasar. Untuk menguji ketepatan model, penulis menempatkan 2016 sebagai periode perkiraan.
\end{abstract}

Kata kunci: Prediksi Kegagalan, Diskrit-Time Hazard Model, Perusahaan Asuransi. 


\section{INTRODUCTION}

The main objective of estimation model for financial insolvency is to compose a variable that can be used to assess bankruptcy probability in the industry using fundamental information of the observed firm (Mansi, William, \& Zhang, 2010). There were four models introduced in the early development of default prediction models that have been popular among academics and practitioners, i.e., Beaver (1966), Altman (1968), and Ohlson (1980).

It was Beaver (1966) who introduced the first default prediction model using individual financial ratio (univariate model). Trying to improve the performance of Beaver's model, Altman (1968) designed a multivariate discriminant analysis (MDA) model using five financial ratios and introduced Altman Z-score. Several years later, Ohlson (1980) found drawbacks on Altman Z-score measurement, i.e., normality assumption and group dispersion, and therefore, introduced a prediction model based on logit analysis, which did not require assumptions used in the Altman model. Ohlson model employed single period assessment to determine firms' insolvency magnitude.

The following studies, however, found some weaknesses in the models which led to performance bias. Mansi et al (2010), for example, found empirical proof implying that the models of Altman (1968) and Ohlson (1980) were poorly related to bankruptcy probability and might not be better than debt ratio. Hillegeist et al (2004) even criticized the use of a single period in the Ohlson's logit model for two reasons. Hillegeist et al (2004), firstly, noticed important sampling bias as only one, non-randomly selected sample for every default company, and, secondly, revealed that Ohlson's model tended to produce cross-sectional reliance in the data.

Learning the problem with the single period model (also known as a static model), Shumway (2001) develops hazard model that can avoid all biases incorporated in the static model, such as prediction coefficient bias, inefficiency, and inconsistency. The model has been proven accurate by some studies, such as Abdullah et al (2008).
Moreover, Nam, et al. (2008) extend Shumway's model by placing macroeconomic variable as baseline hazard rate in the hazard model, which is known as dependent hazard model. The study finds that the use of baseline hazard rate default prediction is crucial, particularly when an economy experiences a dramatic change and all companies suffer from the change. The idea is confirmed by Odgen et al. (2003).

In some previous studies, such as Abdullah et al (2008), hazard model has been proven to be superior and be able to overcome drawbacks of the earlier financial distress. This far, there have been very limited number of studies on financial distress prediction using hazard model with Indonesian industry data. Therefore, this paper is aimed at examining whether the discrete-time hazard model would perform well in foreseeing default of companies listed in Indonesia Stock Exchange. In particular, the study assesses the model in insurance industry after the 2008-crises, with interest rate as the baseline hazard rate. The insurance industry was chosen as the sector was quite vulnerable during the USA crises.

\section{LITERATURE REVIEW}

\section{Financial Distress}

There have been some efforts to define indicators of a company experiencing financial distress. Whitaaker (1999) defines negative cash flow as the basis to assess whether a company is under insolvency threat or not. Hofer (1980) further suggests the use of negative net operating income as the discriminant condition of financial distress, while Elloumi and Gueyie (2001) propose negative earning per share as the discriminant basis. Some other criteria basis include negative net worth (Altman, 1993); staff laidoff or dividend payment elimination (Lau, 1987; Hill et al., 1996); interest coverage ratio (Asquith, Gertner, and Scharfstein, 1994); change in equity value (Ross, Wasterfield, \& Jaffrey, 2002; John, Lang, and Netter, 1992); and debt service coverage (Ruster, 1996). This study utilized negative equity as the financial default criterion, similar to that of Altman (1993).

\section{Discrete-Time Hazard Model}

Hazard model is a default estimation model that utilizes time-varying covariates or explanatory variables that vary over time (also known as discrete time hazard 
JURNAL BISNIS \& MANAJEMEN

ISSN 1412 - 3681

model). Hazard model employs each time-series data of the observed company by including each annual data as time-varying covariates.

In the function formulation of the model, survivor function plays an important role. Survivor function provides a probability that a company would survive, while hazard function provides a probability that a company would fail (at t).

Survivor function: $S(t, x ; \theta)=1-\Sigma_{j<t} f(j, x, \vartheta)$

Hazard function : $\Phi(t, x, \theta)=\frac{f(t, x, \vartheta)}{S(t, x, \vartheta)}$

\section{Estimation in Discrete-Time Hazard Function}

Hazard model function is difficult to use since it incorporates non-linear likelihood function and time-varying covariates. Therefore, most studies utilized logit properties to estimate hazard model, as likelihood function in the hazard model is similar with likelihood function in the multi-period logit model.

Interpreting logit model as discrete time hazard model can be done by dividing $\theta$ into $\theta_{1}$ and $\theta_{2}$. Thus, hazard function for discrete-time hazard model can be written as follows:

$$
\Phi\left(t, x ; \theta_{1}, \theta_{2}\right)=\frac{1}{1+\exp \left(g(t)^{\prime} \vartheta_{1}+x^{\prime} \vartheta_{2}\right)}
$$

Alternatively, as used in Nam et.al. (2001), the formula of hazard model in logit model can be as follows:

$$
\operatorname{Pr}\left(y_{i, t}=1\right)=\frac{1}{1+\mathrm{e}-\left(\alpha_{t}+x_{i, t},\right)}
$$

To estimate hazard model using logit, each year in which a company survives will be included in the logit sample as the surviving company. Every failure of a company contributes to only 1 failure observation $\left(y_{i, t}=1\right)$ in the logit model.

\section{RESEARCH MRTHODS}

The study employed data from all insurance companies listed in Indonesia Stock Exchange that consistently provided financial statements during the 2008-2015 period (model formation period). From the corporate data, nine financial ratios were chosen using stepwise logistic regression, while interest rate was employed as the baseline hazard rate. The estimation period, i.e., 2016 was used to measure the accuracy of both models in predicting financial distress (model assessment period).

Like in most previous studies, this study used financial ratios as variables for model formation. The model will produce a value between 0 and 1 , which represents default probability or hazard rate. Results of a prediction model will be categorized into three groups, i.e., accurate estimation, estimation error I, and estimation error II, based on particular cut-off point (Santoso, 1996). The cut-off point is a value that determines the category of a sample, after probability calculation. Santoso (1996) and Duda and Schmidt (2010) suggest that proportion of default and the non-default sample is the best criterion for setting the cut-off point.

Financial ratios were chosen based on three previous studies, i.e., (i) Shumway (2001); (ii) Abdullah et al. (2008); and (iii) Tsai and Chang (2010). They were:

Table 1 Financial Ratios Used in the Model Formation

\begin{tabular}{llll}
\hline No. & \multicolumn{1}{c}{ Financial ratio } & Ratio Category & Reference \\
\hline 1 & Total liabilities to total assets & Leverage & (3) \\
2 & Retained earning to total assets & ROI & $(1),(3)$ \\
3 & Current assets to current liabilities & Liquidity & $(1),(2),(3)$ \\
4 & Cash to current liabilities & Liquidity & $(2)$ \\
5 & Sales to total assets & Productivity & $(1),(3)$ \\
6 & Cash to total assets & Productivity & $(2)$ \\
7 & Market equity to total liabilities & Equity & $(1),(3)$ \\
8 & EBIT to total assets & ROI & $(1),(3)$ \\
9 & Net income to total assets & ROI & $(1),(2),(3)$ \\
10 & Net income to owners' equity & ROI & $(2)$ \\
11 & Working capital to total assets & Investment & $(1),(3)$ \\
\hline
\end{tabular}

Source: (i) Shumway (2001); (ii) Abdullah et al. (2008); and (iii) Tsai and Chang (2010)

Eleven insurance companies had been listed in the IDX during 2008-2015 period. Based on judgment sampling, only 8 companies were selected in the study. They were divided into 2 sub-samples, i.e., the sample for model formation (5 companies) and for model validation (hold-out sample). Table 2 shows the sample division. 
The sample included in the model formation is 8 , consisting of 3 companies experiencing financial distress and 5 non-distress companies. Thus, the cutoff point is $0.25(=1 / 4)$.

Table 2 Sample Grouping Based on Status and Data Usage Period

\begin{tabular}{|c|c|c|c|c|}
\hline & & \multicolumn{2}{|c|}{ Status } & \multirow{2}{*}{ Total } \\
\hline & & Distress & Non-Distress & \\
\hline \multirow[t]{3}{*}{ Period } & Training & 1 & 4 & 5 \\
\hline & Estimation & 1 & 2 & 3 \\
\hline & Total & 2 & 6 & 8 \\
\hline
\end{tabular}

Source: data processed

This study utilized discrete time hazard model in estimating financial distress. Financial ratios used for model formation and for hazard rates determination were pooled data. Thus, the number of observation is 31 firm-years model formation sample and 18 firmyears for the hold-out sample. Table 3 shows the detail of data division:

Table 3 Sample Grouping Based on Firm-Years

\begin{tabular}{lccccc}
\hline & & \multicolumn{2}{c}{ Status } & \\
\cline { 3 - 5 } & & & $\begin{array}{c}\text { Distress } \\
\text { firm-years }\end{array}$ & $\begin{array}{c}\text { Non-distress } \\
\text { firm years }\end{array}$ & Total \\
\hline \multirow{2}{*}{ Period } & Training & & 1 & 30 & 31 \\
\cline { 2 - 5 } & Estimation & & 2 & 16 & 18 \\
& \multicolumn{2}{c}{ Total } & 3 & 46 & 49 \\
\hline
\end{tabular}

The number of non-distress firm years were obtained from the number of surviving observed firms during the training period. Companies with financial distress were included in the sample until a period they were in sound status. Therefore, each distress firm $(Y=1)$ only contributed $\mathrm{Y}=1$ once during the training period (2008-2008).

\section{RESULTS AND DISCUSSION}

\section{Descriptive Statistic}

Descriptive Statistic Analysis was done to see the average of financial ratios of firms experiencing financial distress and sound firms. Table 4 shows a descriptive statistic of 11 financial ratios observed in this study.
Table 4 Descriptive Statistic Analysis: Financial Ratio of Financial Distress and Non-Financial Distress Firms

\begin{tabular}{lcccccccc}
\hline & \multicolumn{4}{c}{ Financial distress } & \multicolumn{4}{c}{ Non-Financial distress } \\
\cline { 2 - 8 } & N & Min & Max & Mean & N & Min & Max & Mean \\
\hline X1 & 2 & 1.102 & 1.91 & 1.33 & 29 & 0.057 & 0.981 & 0.513 \\
X2 & 2 & -1.2097 & -0.4003 & -0.9080 & 29 & -7.3473 & 2.3197 & 0.2633 \\
X3 & 2 & 0.1016 & 3.5113 & 0.8783 & 29 & 0.7429 & 33.9898 & 2.0233 \\
X4 & 2 & 0.0013 & 0.9007 & 0.3997 & 29 & 0.0077 & 3.0021 & 0.3333 \\
X5 & 2 & 0.0671 & 1.4001 & 0.5378 & 29 & 0.3207 & 2.5377 & 2.2763 \\
X6 & 2 & 0.0026 & 0.1096 & 0.0619 & 29 & 0.0072 & 0.4191 & 0.0774 \\
X7 & 2 & -0.6190 & -0.0937 & -0.3135 & 29 & 0.0473 & 16.9229 & 2.5044 \\
X8 & 2 & -0.1073 & 0.0916 & -0.0750 & 29 & -0.7377 & 0.4878 & 0.0344 \\
X9 & 2 & -0.6091 & 0.0603 & -0.3411 & 29 & -0.2693 & 0.3118 & 0.0422 \\
X10 & 2 & -0.0906 & 3.9331 & 0.9388 & 29 & -2.9322 & 6.3875 & 0.2202 \\
X11 & 2 & -1.6127 & 0.1497 & -1.0538 & 29 & -0.6723 & 0.8119 & 0.2553 \\
\hline
\end{tabular}

Source: Processed data

Table 4 shows that average total liabilities to total assets and net income to equity of financial distress firms were higher than those of non-financial distress ones. On the other side, the rest of ratios (retained earning to total assets, earning before interest and tax to total assets, net income to total assets, current assets to current liabilities, cash to current liabilities, sales to total assets, cash to total assets, equity to total liabilities, and working capital to total assets) were lower than those of non-financial distress firms.

\section{Model Formation}

The financial distress prediction model was developed using the selected financial ratios that determine whether a firm would face financial distress or not.

In the first stage, all observed firms in the training period were assessed whether they experienced financial distress ( $Y=1$, negative equity) or not $(\mathrm{Y}=0$, positive equity). In the next stage, the author calculated the 11 financial ratios from each sample. In the third stage, financial ratios were screened to obtain ratios that could significantly determine whether a firm faced distress or not, using 5\%-significance level of the log-rank test. Table 5 shows the results of the log-rank test: 
Table 5 Results of Log-Rank Test on the Financial Ratios

\begin{tabular}{cc}
\hline Variable & Significance Level \\
\hline X1 & 0.177 \\
X2 & 0.177 \\
X3 & $0.017^{*}$ \\
X4 & $0.011^{*}$ \\
X5 & $0.017^{*}$ \\
X6 & $0.01^{*}$ \\
X7 & $0.017^{*}$ \\
X8 & $0.011^{*}$ \\
X9 & $0.037^{*}$ \\
X10 & $0.011^{*}$ \\
X11 & $0.017^{*}$ \\
\hline
\end{tabular}

*Significant at 5\% level

Source: Processed data
It can be seen from Table 5 that all ratios were significant, except for $\mathrm{X} 1$ (total liabilities to the total asset) and $X 2$ (retained earning to the total asset). Therefore, in the following stage, those 2 variables were not included.

In the fourth stage, the author conducted correlation test among the ratios using Spearman Correlation Test at $5 \%$ significance level. Table 6 shows the results of Spearman Correlation Test:

Table 6 Spearman Correlation Test Result

\begin{tabular}{|c|c|c|c|c|c|c|c|c|c|c|c|}
\hline & & & X3 & $\mathrm{X} 4$ & X5 & $\mathrm{x} 6$ & $x 7$ & $\mathrm{x} 8$ & $x 9$ & $\mathrm{X} 10$ & X11 \\
\hline \multirow[t]{27}{*}{ Spearman's rho } & X3 & Correlation Coefficient & 1.000 & $-.611 * *$ & $-.609 * *$ & $-.228^{* *}$ & $-.898 * *$ & $-.201 * *$ & $-.272^{* *}$ & -.011 & $-.686^{* *}$ \\
\hline & & Sig. (2-tailed) & . & .000 & .000 & .000 & .000 & .002 & .000 & .848 & .000 \\
\hline & & $\mathbf{N}$ & 49 & 49 & 49 & 49 & 49 & 49 & 49 & 49 & 49 \\
\hline & $X 4$ & Correlation Coefficient & $-.611 * *$ & 1.000 & $.581^{* *}$ & $.511^{* *}$ & $.622^{* *}$ & $.641^{* *}$ & $.629 * *$ & $.202 * *$ & $.609 * *$ \\
\hline & & Sig. (2-tailed) & .000 & . & .000 & .000 & .000 & .000 & .000 & .000 & .000 \\
\hline & & $\mathbf{N}$ & 49 & 49 & 49 & 49 & 49 & 49 & 49 & 49 & 49 \\
\hline & $\mathrm{X} 5$ & Correlation Coefficient & $-.609 * *$ & $.581^{* *}$ & 1.000 & $.211^{* *}$ & $.682^{* *}$ & $.288^{* *}$ & $.221^{* *}$ & .022 & $.918^{* *}$ \\
\hline & & Sig. (2-tailed) & .000 & .000 & . & .000 & .000 & .002 & .000 & .621 & .000 \\
\hline & & $\mathbf{N}$ & 49 & 49 & 49 & 49 & 49 & 49 & 49 & 49 & 49 \\
\hline & $\mathrm{x} 6$ & Correlation Coefficient & $-.228 * *$ & $.511 * *$ & $.211^{* *}$ & 1.000 & $.215^{* *}$ & $.511 * *$ & $.481 * *$ & $.211 * *$ & $.488^{* *}$ \\
\hline & & Sig. (2-tailed) & .000 & .000 & .000 & . & .000 & .000 & .000 & .005 & .000 \\
\hline & & $\mathbf{N}$ & 49 & 49 & 49 & 49 & 49 & 49 & 49 & 49 & 49 \\
\hline & X7 & Correlation Coefficient & $-.898 * *$ & $.622 * *$ & $.682 * *$ & $.215^{* *}$ & 1.000 & $.286 * *$ & $.245 * *$ & .018 & $.851 * *$ \\
\hline & & Sig. (2-tailed) & .000 & .000 & .000 & .000 & . & .001 & .000 & .660 & .000 \\
\hline & & $\mathbf{N}$ & 49 & 49 & 49 & 49 & 49 & 49 & 49 & 49 & 49 \\
\hline & X8 & Correlation Coefficient & $-.201 * *$ & $.641^{* *}$ & $.288 * *$ & $.511 * *$ & $.286 * *$ & 1.000 & $.814^{* *}$ & $.522 * *$ & $.226 * *$ \\
\hline & & Sig. (2-tailed) & .002 & .000 & .002 & .000 & .001 & . & .000 & .000 & .000 \\
\hline & & $\mathbf{N}$ & 49 & 49 & 49 & 49 & 49 & 49 & 49 & 49 & 49 \\
\hline & X9 & Correlation Coefficient & $-.222 * *$ & $.629 * *$ & $.221 * *$ & $.481 * *$ & $.245 * *$ & $.814^{* *}$ & 1.000 & $.868 * *$ & $.429 * *$ \\
\hline & & Sig. (2-tailed) & .000 & .000 & .000 & .000 & .000 & .000 & . & .000 & .000 \\
\hline & & $\mathbf{N}$ & 49 & 49 & 49 & 49 & 49 & 49 & 49 & 49 & 49 \\
\hline & $\mathrm{X} 10$ & Correlation Coefficient & -.011 & $.202 * *$ & .022 & $.211 * *$ & .018 & $.522 * *$ & $.868 * *$ & 1.000 & .120 \\
\hline & & Sig. (2-tailed) & .848 & .000 & .621 & .005 & .660 & .000 & .000 & . & .122 \\
\hline & & $\mathbf{N}$ & 49 & 49 & 49 & 49 & 49 & 49 & 49 & 49 & 49 \\
\hline & $\mathrm{x} 11$ & Correlation Coefficient & $-.686 * *$ & $.609 * *$ & $.918 * *$ & $.488 * *$ & $.851 * *$ & $.226^{* *}$ & $.429 * *$ & .120 & 1.000 \\
\hline & & Sig. (2-tailed) & .000 & .000 & .000 & .000 & .000 & .000 & .000 & .122 & . \\
\hline & & $\mathbf{N}$ & 49 & 49 & 49 & 49 & 49 & 49 & 49 & 49 & 49 \\
\hline
\end{tabular}


Based on the results of spearman test, there were several variables with high correlation coefficients (significant at $1 \%$ level) and should be discarded from the process. After the correlation test, only three variables left, i.e., X2 (current assets to current liabilities), X5 (sales to total assets), and X9 (net income to total assets).

In the last stage, the remaining ratios were selected for model formation based on their significance level. The process utilized Stepwise Logistic with a significance level of $10 \%$.

Table 7 The Results Of Case Processing Summary Of Model With Baseline Hazard Rate

MODEL WITH BASELINE HAZARD RATE

\begin{tabular}{llcc}
\hline Unweighted Casesa & N & Percent \\
\hline Selected Cases & Included in Analysis & 49 & 100.0 \\
& Missing Cases & 0 & .0 \\
& Total & 49 & 100.0 \\
Unselected Cases & & .0 & .0 \\
Total & 49 & 100.0 \\
\hline Source: Processed data & &
\end{tabular}

A number of observations included was 49. If the test was done using multi-period logit model, the number would be 8 , just like number of sample, since used in the study was averages of the observed periods. In hazard model, each distress firm contributes only once, i.e., firms facing distress at $t$ will not be included as sample in period $t+1$. Table 7 shows that $100 \%$ of the observations can be assessed by stepwise logistic model.

Table 8 Results of Hosmer and Lemeshow Test

\begin{tabular}{cccc}
\hline \multicolumn{5}{c}{ MODEL WITH BASELINE HAZARD RATE } \\
\hline Step & Chi-square & $\mathrm{df}$ & Sig. \\
\hline $\mathbf{1}$ & 14.521 & 8 & .073 \\
$\mathbf{2}$ & 14.813 & 8 & .072 \\
\hline
\end{tabular}

Hosmer and Lemeshow test is to examine goodness of fit of the model. Table 8 shows that Chi-square of the logistic regression model is 14.813 with the significance of 0.072 , implying the model can be used.
Table 9 Model Summary of Stepwise Logistic

\begin{tabular}{cllc}
\hline \multicolumn{4}{c}{ MODEL WITH BASELINE HAZARD RATE } \\
\hline Step & $\mathbf{- 2 ~ L o g ~ l i k e l i h o o d ~}$ & $\begin{array}{l}\text { Cox \& Snell R } \\
\text { Square }\end{array}$ & $\begin{array}{c}\text { Nagelkerke R } \\
\text { Square }\end{array}$ \\
\hline $\mathbf{2}$ & $22.002^{\mathrm{a}}$ & .202 & .679 \\
$\mathbf{2}$ & $27.822^{\mathrm{b}}$ & .228 & .729 \\
\hline
\end{tabular}

Source: processed data

Table 9 shows a summary of the logistic regression model. The value of -2 Log Likelihood is 27.822, decreased from 22.002 (initial iteration). The decline indicated that addition of variable in each iteration had increased model fit by 3.280 . The value of Nagelkerke R Square is 0.729 , meaning that $72.9 \%$ of the variability of dependent variable can be explained by independent variables.

Table 10 Variable Forming Model with Baseline Hazard Rate

\begin{tabular}{lllccccc}
\hline \multicolumn{7}{c}{ MODEL WITH BASELINE HAZARD RATE } \\
\hline \multirow{2}{*}{ Step 2 $^{\mathrm{a}}$} & X9 & B & S.E. & Wald & df & Sig. & Exp(B) \\
\cline { 3 - 8 } & Constant & -4.208 & .928 & 22.922 & 2 & .000 & .022 \\
\multirow{2}{*}{ Step 2 } & X9 & -24.222 & 7.782 & 9.622 & 2 & .002 & .000 \\
& CIR & 48.822 & 29.708 & 2.665 & 2 & .202 & $2.590 \mathrm{E} 22$ \\
& Constant & -20.655 & 4.422 & 5.622 & 2 & .027 & .000 \\
\hline
\end{tabular}

a. Variable(s) entered on step 2: X9.

b. Variable(s) entered on step 2: CIR.

Source: Processed data

Table 10 shows that financial ratio included in the model with baseline hazard rate was X9 with the coefficient of -24.222 , significant at $2 \%$. This result also shows that macroeconomic variable used was the CIR (change in interest rates, the coefficient of 48.822).

The model formation result was as follows:

Discrete time hazard model with change in Interest rate as baseline hazard rate

$$
\operatorname{Pr}(Y i, t=1)=\frac{1}{1+e-\left(\left(48.811(t)+\left(-10.655-24.111 X_{g}\right)\right)\right.}
$$

\section{Model Assessment and Validation}

The model was then assessed and validated using cut-off-value of 0.25 . Table 11 shows the assessment result, in which the model was found accurate $90.32 \%$. 
JURNAL BISNIS \& MANAJEMEN

ISSN 1412 - 3681

Table 11 Model Assessment Result with Cut-Off Point of 0.25

\begin{tabular}{llcccc}
\hline \multicolumn{5}{c}{ MODEL WITH BASELINE HAZARD RATE } \\
\hline & & \multicolumn{2}{c}{ PREDICTION } & \\
\cline { 3 - 5 } & & Distress & $\begin{array}{c}\text { Non- } \\
\text { Distress }\end{array}$ & Total & Correct \\
\cline { 3 - 5 } Status 2016 & Distress & 2 & 0 & 2 & 1 \\
& Non-Distress & 0 & 29 & 29 & 27 \\
& & & & 31 & 28 \\
& & & & $100 \%$ & $90.32 \%$ \\
\hline
\end{tabular}

Source: Processed data

Meanwhile, Table 12 indicates that the model is highly accurate as the prediction was correct $94.44 \%$.

Table 12 Model Validation Test Result with Cut-Off Point of $\mathbf{0 . 2 5}$

\begin{tabular}{llcccc}
\hline \multicolumn{5}{c}{ MODEL WITH BASELINE HAZARD RATE } \\
\hline & & \multicolumn{2}{c}{ PREDICTION } & & \\
\cline { 3 - 5 } & & Distress & $\begin{array}{c}\text { Non- } \\
\text { Distress }\end{array}$ & Total & Correct \\
\cline { 3 - 5 } Status 2016 & Distress & 1 & 0 & 1 & 1 \\
& Non-Distress & 0 & 17 & 17 & 16 \\
& & & & 18 & 17 \\
& & & & $100 \%$ & $94.44 \%$ \\
\hline
\end{tabular}

Source: Processed data

\section{Discussion}

The movement of SBI (a proxy of interest rate change) relies much on the view of Bank Indonesia in anticipating the potential inflation rate movement, as well as liquidity in the economy. At the same time, SBI fluctuation will stimulate interest rate changes in loan and deposit, as well as in any other financial instrument. Moreover, high inflation will increase operation cost in any investment. Therefore, it can be inferred that increase in SBI will lead to higher probability of a company facing financial distress, including insurance companies.

This study found that the model was accurate at $90 \%$. This might signal that the dramatic changes during the crises placed insurance companies in unfavorable condition, both in supply and demand sides. The validation test model using hold-out sample also indicated that the model was quite valid to predict financial distress, as the precision was $94 \%$.

The above findings at least implied that inclusion of macroeconomic variable enhances the accuracy of
Jurnal Bisnis \& Manajemen, 2017, Vol. XVIII, No. 1, 55-62

the prediction model, confirming Nam et. al. (2008). The crises circumstance has also proven to boost the accuracy.

\section{CONCLUSION AND RECOMMENDATION}

Using 31 firm-years data for the model formation and 18 firm-years data for model validation, this study found that default prediction model with interest rate change as baseline hazard rate was pretty accurate and valid. The model was even more precise for crises period data.

\section{REFERENCE}

Abdullah, N.A.H., A. Halim., H. Ahmad., and, R.M. Rus. (2008). Predicting corporate failure of Malaysia's listed companies: comparing multiple discriminant analysis, logistic regression and the hazard model. International Research Journal of Finance and Economics. ISSN 1450-2887 Issue 15.

Altman, E.I. (1968). Financial ratios, discriminant analysis, and the prediction of corporate bankruptcy. Journal of finance 23: 589-609.

- (1993). Corporate Financial Distress and Bankruptcy, 2nd edition. New York: Wiley

Asquith, P., R. Gertner., \& D. Scharfstein. (1994). Anatomy of financial distress: an examination of junk-bond issuers. Quarterly Journal of Economics 109: 1189-1222.

Beaver, W. (1966). Financial ratios as predictors of failure: empirical research in accounting: selected studies. Journal of Accounting Research (supplement) 4: 71-111.

Duda, Matej. and Henning Schmidt. (2010). Bankruptcy prediction: Static logit model versus discrete time hazard models incorporating macroeconomic dependencies. Master Thesis Lund Universtiy.

Elloumi and Gueyie. (2001). Financial distress and corporate governance: an empirical 
analysis. Corporate Governance: 15-23. MCB University Press.

Hill, N.T., S.E. Perry, and S. Andres. (1996). Evaluating firms in financial distress: an event history analysis. Journal of Applied Business Research 12(3): 60-71.

Hillegeist, S.A., Keating E.K., Cram D.P., and Lundstedt K.G. (2004). Assessing the probability of bankruptcy. Review of Accounting Studies 9: 5-34.

Hofer, C.W. (1980). Turnaround strategies. Journal of Business Strategy 1: 19-31.

John, K., L.H.D. Lang, and Netter. (1992). The voluntary restructuring of large firms in response to performance decline. Journal of finance 47: 891-917.

Lau, A.H. (1987). A Five state financial distress prediction model. Journal of Accounting Research 25: 127-138.

Mansi, S.A., F.M William, and A. Zhang. (2010). Bankruptcy Prediction Models and the Cost of Debt. Journal of Fixed Income, 2010.

Nam, C.W., T.S. Kim, N.J. Park, and H.K. Lee. (2008). Bankruptcy prediction using a discrete-time duration model incorporating temporal and macroeconomic dependencies. J. Forecast 27: 493-506.
Odgen, G.I., F.J. Jen, and P. Conner. (2003). Advanced Corporate Finance: Policies and Strategies. New Jersey: Prentice Hall.

Ohlson, J.A. (1980). Financial ratios and probabilistic prediction on bankruptcy. Journal of Accounting Research 18: 109-131.

Ross, S.A., R.W. Westerfield, and Jaffrey J. (2002). Corporate Finance 6th $\mathrm{Pkg}$ Edition. USA. McGraw-Hill.

Ruster, J. (1996). Mitigating Commercial Risks in Project Finance: Public Policy for Private.

Santoso, Wimboh. (1996). The Determinants of Problem Banks in Indonesia. Banking Research and Regulation, Bank Indonesia.

Shumway, T. (2001). Forecasting bankruptcy more accurately: a simple hazard model. The Journal of Business 74: 101-124.

Tsai, B-H and C-H Chang. (2010). Predicting financial distress based on the credit cycle index: a two-stage empirical analysis. Emerging Markets Finance \& Trade / May-June 2010, Vol. 46, No. 3: 67-69.

Whitaaker, R. B. (1999). The early stages of Financial Distress. Journal of Economics and Finance 23:123-133. 